\title{
Knowledge, attitude and practice of the Sudanese people towards COVID-19: an online survey
}

\author{
Amal Abdelrahim Osman Mohamed ${ }^{1 *}$ (D), Eilaf Ali Mohamed Elhassan', Abdelrahim Osman Mohamed², \\ Awab Aldow Mohammed ${ }^{3}$, Hassan Alshaikh edris ${ }^{3}$, Mohamed Alhadi Mahgoop ${ }^{3}$, Mohamed Emadaldin Sharif ${ }^{3}$, \\ Maab Imadeldin Bashir ${ }^{3}$, Rania Bashir Abdelrahim³ ${ }^{3}$ Wegdan Ibraheim Idriss ${ }^{3}$ and Elfatih Mohamed Malik ${ }^{2}$
}

\begin{abstract}
Background: The Novel Corona virus SARS-CoV-2 emerged to affect the human population in 2019 causing COVID19 pandemic. The only preventive measures available are social distancing, hand washing and face masks. This study aims to assess the knowledge, attitude and practice of the Sudanese people towards COVID-19.

Methods: An online cross-sectional study targeting adult Sudanese people was conducted in April 2020. The study used a self-administered questionnaire containing 18 knowledge questions, 5 questions for attitude and six questions for practices. Social media such as Facebook and WhatsApp were utilized to disseminate the questionnaire. The total number of eligible questionnaires available for analysis by the end of the period was 987.

Results: The mean $( \pm$ SD) age of respondents was $30.13( \pm 9.84)$ years with males representing $55.4 \%$. The majority were university and higher education levels (95.2\%), residing in Khartoum (71.7\%). The mean ( \pm SD) knowledge score of the participants was $15.33( \pm 2.24)$ and was found to be associated with education level and age groups $(p$-value $=0.022, P$ value $=0.010)$ respectively. The mean $( \pm$ SD) attitude score was $04.15( \pm 0.97)$ and was significantly associated with older groups and better-educated participants ( $p$-value $=0.001, p$-value $=0.048$ ) respectively. The practices related to COVID-19 preventive measures mean $( \pm$ SD) was $02.58( \pm 1.73)$ with a significant difference between age groups and area of residence.

Conclusions: This study showed that the participants had good knowledge and satisfactory attitude that was not similarly expressed into practice. Efforts are needed in health education and law enforcement to improve the practices among all groups with special emphasis on younger and less educated males.
\end{abstract}

Keywords: COVID-19, Coronavirus, Sudan, KAP study

\section{Background}

The emergence of a new coronavirus SARS CoV-2 causing the COVID- 19 disease characterized by a wide range of symptoms and a wide range of clinical presentations (from asymptomatic to severe acute pneumonia and other multi-organ complications) represents a real

\footnotetext{
* Correspondence: Amalmohamed.sud@gmail.com

${ }^{1}$ Federal Ministry of Health, Khartoum, Sudan

Full list of author information is available at the end of the article
}

threat to population worldwide [1]. The spread of the disease triggered the World Health Organization (WHO) to declare a pandemic status on March 11, 2020. Mitigation action were then followed by strong containment measures worldwide [2, 3].

The prevalence and emergence of the disease depends on infectivity and virulence of the virus itself; in addition to the interaction of the social environment, economic activities and people mobility [4]. It is clear so far that

C C The Author(s). 2021 Open Access This article is licensed under a Creative Commons Attribution 4.0 International License, which permits use, sharing, adaptation, distribution and reproduction in any medium or format, as long as you give appropriate credit to the original author(s) and the source, provide a link to the Creative Commons licence, and indicate if changes were made. The images or other third party material in this article are included in the article's Creative Commons licence, unless indicated otherwise in a credit line to the material. If material is not included in the article's Creative Commons licence and your intended use is not permitted by statutory regulation or exceeds the permitted use, you will need to obtain permission directly from the copyright holder. To view a copy of this licence, visit http://creativecommons.org/licenses/by/4.0/ The Creative Commons Public Domain Dedication waiver (http://creativecommons.org/publicdomain/zero/1.0/) applies to the data made available in this article, unless otherwise stated in a credit line to the data. 
COVID-19 is rapidly spreading but the other virus aspects are not clear yet COVID- 19 virus does not have a vaccine yet, and the best way for prevention is by handwashing, social distancing, and facemask $[3,5,6]$. The first coronavirus case in Sudan was declared on March 12, 2020. Since then many cases were reported. All of these cases had recent history of travel to affected countries or close contact with a person returning from countries with reported cases. The government closed all land crossings, air and seaports and announced a public health emergency [7]. On April 18, 2020, the Sudanese government commanded total lockdown for 3 weeks in Khartoum (the capital of Sudan where most of the cases were reported) to delay the transmission of the disease. The government complained of the poor commitment of the community to the health emergency, especially during the allowed hours. To the time of writing this paper; May 6, 2020; the number of diagnosed COVID-19 cases in Sudan was 852 with 80 cases recovered and 49 deaths [8].

Sudan is the third-largest country in Africa, with approximately $60 \%$ of the population below 30 years old; Sudan has a diverse population with different cultures and religions. Besides the rich human resources, the country has many natural agricultural, animal, and mineral resources [9]. However, Sudan is also suffering from many disparities, inequalities, and civil wars that had affected various indicators.

According to the latest Multiple Indicator Cluster Survey (MICS 2014), the literacy rate among young people was $59.8 \%$ and the use of treated water was $4.1 \%$ while those who had places for handwashing were $25.8 \%$ [10]. These indicators affect how the Sudanese people respond to a pandemic such as COVID-19 that requires a high level of knowledge, and hygienic practices.

On the other hand, the country health system has been affected by the double burden of communicable and non-communicable disease with the emergence of multiple epidemics in recent years (cholera in Blue Nile state, malaria in west and chikungunya in the eastern region) [11]. All these factors plus the dramatically changing political and economic situations after the peaceful revolution made an enormous pressure on the country response to this crisis.

KAP study is a tool to understand the awareness and practices of the public towards the COVID-19 assess gaps in knowledge, practices, and preventive measures [12] the importance of this KAP study is to understand the characteristics of the community and their perception toward COVID-19, which will allow the authorities to take effective measures [13] also the control of COVID-19 depends on the community commitment rather than health regulation so recognizing the existing perception and practices may help to identify attributes that influence the public in adopting health practices and responsive behaviors [14].

This study aims to assess the knowledge, attitude, and practices of the Sudanese population towards COVID-19 to date.

\section{Methods}

This is a descriptive cross-sectional online survey conducted through a self-administered questionnaire targeting adult Sudanese people who were living inside and outside Sudan. (The inclusion criteria were all Sudanese population, aged 18 years and more). The questionnaire was designed using Google form online questionnaire that was accessible by clicking on a link; it was disseminated by the investigators using social media such as Facebook and WhatsApp. To minimize Bias and maximize the diversity of responses the investigators distributed the questionnaire among known Sudanese Facebook pages, Whatsap groups, and advertisement Whatsap groups (paid) that have thousands of subscribers, which further disseminated the questionnaire (snowballing). The investigators followed those groups and reminded them on daily basis until the target date was reached.

The minimum sample size was calculated using the Open Epi-calculator (https://www.openepi.com/ SampleSize/SSPropor.htm) to be 385, taking the margin of error as $5 \%$, confidence interval at $95 \%$, estimated population 40 million according to the 2008 census population projection. However, all responses during the period from April 7, 2020, to April 13, $2020(n=1013)$ were included to improve validity. Only 987 were included in the final analysis after exclusion of those less than 18 years, duplicates and those who did not give a consent.

\section{Data collection tool}

The data collection tool was adapted with modifications from an online survey done in Chinese population and WHO COVID-19 rapid quantitative assessment tool [6, 15]. The questionnaire consisted of 29 items and divided into two parts (attached in the supplementary appendix). The first part investigated demographic variables and general information including age, gender, residence, and education status. The second part consisted of -multiple choice questions and yes/no questions- 4 knowledge areas with 18 questions (mode of transmission, symptoms, at-risk groups, preventive measures); 5 attitude questions (the danger of the disease, handwashing, masks use, social distancing and isolation of diseased patients) and 3 practices areas (handwashing, social distancing and handshaking) including questions about family practice regarding the use of mask and social distancing. 


\section{Data management}

The knowledge, attitude and practices scores were calculated as one for yes answer and zero for no answer. Then each item was calculated separately. The mean and standard deviation for the knowledge attitude and practices scores were obtained. In the practices the Yes frequently answer were considered as yes while yes sometimes and no were considered as no. .

\section{Data analysis}

Data was analyzed using IBM SPSS version 25. Frequencies were described for all independent and dependent variables. Then analysis of variance using a t-test and $\mathrm{F}$ test to determine the association between knowledge, attitude and practice and the independent variables of age, gender, and residence and education status was done. Binary logistic regression was used to determine factors associated with knowledge and practices scores (the good knowledge and practices were considered as scores above the mean). The statistical significance level was set at $p<0.05$.

\section{Results}

The mean $( \pm$ SD) age of the study sample was 30.13 years $( \pm 9.84)$. Males represent $55.6 \%(n=549)$ of the subjects. The majority of the respondent's education level was university and more (95.2\%) and most of them resided in Khartoum state (Table 1). The awareness about COVID-19 pandemic was found to be $91.3 \%$ among the study population; the major source of information was official websites of the Ministry of Health $(\mathrm{MOH})$ and WHO (Table 1).

The mean knowledge score was found to be 15.33 ( \pm $2.24)$ with the older group $(30+$ years $)$ having a significantly higher mean of knowledge $(P$-value $=0.010)$. There was a significant difference between the education groups in the means of knowledge scores towards COVID-19 $(p$-value $=0.022)$ (Tables 2 and 3$)$.

The overall attitude score of the participants was 04.15 ( \pm 0.97); and there was significant difference between the age groups ( $\mathrm{P}$-value $=0.001)$ as well as different levels of education $(P$-value $=0.048)$. On the other hand, the mean practices score was 02.58 ( \pm 1.73 ), with a significant difference between age groups and area of residence (Tables 2 and 3).

Table 1 Sociodemographic characteristics of the participants $(n=987)$

\begin{tabular}{|c|c|c|}
\hline Variable & Frequency & Percentage (\%) \\
\hline \multicolumn{3}{|l|}{ Age groups in years } \\
\hline Less than 30 years & 576 & 58.4 \\
\hline 30 years and more & 411 & 41.6 \\
\hline Mean $( \pm S D)$ age in years & $30.13( \pm 9.84)$ & \\
\hline \multicolumn{3}{|l|}{ Gender } \\
\hline Female & 438 & 44.4 \\
\hline Male & 549 & 55.6 \\
\hline \multicolumn{3}{|l|}{ Highest education level } \\
\hline Basic education & 47 & 4.8 \\
\hline University and more & 940 & 95.2 \\
\hline \multicolumn{3}{|l|}{ Residence } \\
\hline Khartoum State & 708 & 71.7 \\
\hline Other states & 168 & 17.0 \\
\hline Sudanese but currently outside Sudan & 111 & 11.2 \\
\hline \multicolumn{3}{|l|}{ Awareness about COVID-19 pandemic } \\
\hline Yes & 901 & 91.3 \\
\hline No or not sure & 86 & 8.7 \\
\hline \multicolumn{3}{|l|}{ Source of knowledge ( $\mathrm{n}$ for each is 987 ) } \\
\hline Official websites (e.g. MOH, WHO) & 775 & 78.5 \\
\hline Social media & 471 & 47.7 \\
\hline Mass media & 463 & 46.9 \\
\hline Public health/ hospitals banners & 411 & 41.6 \\
\hline Health personnel & 244 & 24.7 \\
\hline Social talks (friends, family and co-workers) & 213 & 21.6 \\
\hline
\end{tabular}


Table 2 Knowledge, attitude and practice of COVID-19 among Sudanese

\begin{tabular}{|c|c|}
\hline Variable & $\begin{array}{l}\text { Frequency } \\
\text { (\%) }\end{array}$ \\
\hline \multicolumn{2}{|l|}{ Knowledge } \\
\hline \multicolumn{2}{|l|}{ A. COVID-19 can be transmission through } \\
\hline 1. Airborne & $276(28.0)$ \\
\hline 2. Droplets & $881(89.3)$ \\
\hline 3. Fomite and surfaces & $878(89.0)$ \\
\hline \multicolumn{2}{|l|}{ B. Symptoms of COVID-19 include } \\
\hline 4. Cough & $846(85.7)$ \\
\hline 5. Fever & $916(92.8)$ \\
\hline 6. Headache & $865(87.6)$ \\
\hline 7. Tiredness & $736(74.6)$ \\
\hline 8. Difficulty in breathing & $943(95.5)$ \\
\hline 9. Sore throat & $839(85.0)$ \\
\hline \multicolumn{2}{|c|}{ C. Risk of developing severe form of COVID-19 include } \\
\hline 10. Chronic diseases & $789(79.9)$ \\
\hline 11. Pregnancy & $289(29.3)$ \\
\hline 12. Old age & $806(81.7)$ \\
\hline $\begin{array}{l}\text { 13. Any one (irrespective to his health condition or } \\
\text { age) }\end{array}$ & $356(36.1)$ \\
\hline 14. Do not know any risk & $025(02.5)$ \\
\hline \multicolumn{2}{|l|}{ D. Preventive measures for COVID-19 include } \\
\hline 15. Hand washing & $969(98.2)$ \\
\hline 16. Social distancing & $933(94.5)$ \\
\hline 17. Wearing a mask & $760(77.0)$ \\
\hline 18. Antibiotics & $046(04.7)$ \\
\hline 19. Specific medicine for treatment of COVID -19 & $029(02.9)$ \\
\hline \multicolumn{2}{|l|}{ Attitude } \\
\hline $\begin{array}{l}\text { 1. Hand washing is important in controlling the } \\
\text { spread of COVID-19 }\end{array}$ & $912(92.4)$ \\
\hline $\begin{array}{l}\text { 2. Wearing masks is important in controlling the } \\
\text { spread of COVID-19 }\end{array}$ & $491(49.7)$ \\
\hline $\begin{array}{l}\text { 3. Isolation of suspected would prevent the spread } \\
\text { of the virus }\end{array}$ & $918(93.0)$ \\
\hline $\begin{array}{l}\text { 4. Social distancing would prevent the spread of } \\
\text { the virus }\end{array}$ & $889(90.1)$ \\
\hline 5. COVID-19 seems a dangerous disease & $883(89.5)$ \\
\hline \multicolumn{2}{|l|}{ Practice } \\
\hline 1. I am practicing social distancing & $601(60.9)$ \\
\hline 2. I am practicing hand washing frequently & $684(69.3)$ \\
\hline 3. I avoid shaking hands & $266(27.0)$ \\
\hline 4. My family practiced social distancing frequently & $293(29.7)$ \\
\hline 5. My family practiced hand washing frequently & $567(57.4)$ \\
\hline 6. My family used face masks frequently & $133(13.5)$ \\
\hline
\end{tabular}

Table 2 Knowledge, attitude and practice of COVID-19 among Sudanese (Continued)

\begin{tabular}{ll}
\hline Variable & $\begin{array}{l}\text { Frequency } \\
\text { (\%) }\end{array}$ \\
\hline Overall & \\
Overall Knowledge score (Mean \pm SD) & $15.33( \pm 2.24)$ \\
Overall attitude score (Mean \pm SD) & $04.15( \pm 0.97)$ \\
Overall practices score (Mean \pm SD) & $02.58( \pm 1.73)$ \\
\hline
\end{tabular}

Analysis of practice items have shown that: hand washing and avoidance of handshaking were significantly associated with age and area of residence ( $P$-value < 0.001); the data also showed that female practiced hand washing more frequently than males $(P$-value $=$ 0.045) (Table 4).

Further analysis of the data using binary logistic regression (Tables 5, 6) displayed that better knowledge was associated with older age and higher education. Moreover, better practices were associated with older age and female gender. There was no significant association between the practices and the knowledge and attitude.

\section{Discussion}

This study was performed in a time of a quickly changing evidence and rapid spread of the coronavirus. The study was performed among the Sudanese population using smartphones and social media that explain why the majority of the population were young, living in Khartoum state and were university or highly educated. This was also the case in previous $t$ quick online surveys on COVID-19 [6, 14, 16-18].

The high awareness in this study can be explained by the explosive flow of information on all platforms especially after the appearance of the first case of the disease in the country similar to what happened in China [6]. The sources of knowledge were mainly official websites (internet) and social media. The Sudanese Federal Ministry of Health has a well-established with thousands of flowers, continuously updated social media page and an official website. The wide access to the social media carries the risk of infodemics which the authorities should mitigate by proper risk communication [17, 18]. Similar to what happened in Egypt, hydroxychloroquine ran out of the stocks in Sudan after rumors of its promising effect on COVID-19 [17].

The knowledge of the population was high and this may be attributed to the characteristics of the study population, it is also a feature found in other countries in the region [17-20]. However, another multinational study indicated lower knowledge in countries in the region (Jordan, Kuwait and Saudi Arabia) [21]. The data revealed that well-educated and older persons had better knowledge about the COVI-19; this can be used to 
Table 3 Predictors of Sudanese knowledge, attitude and practices related to COVID-19

\begin{tabular}{|c|c|c|c|c|c|c|c|c|c|}
\hline \multirow[t]{2}{*}{ Factor variables } & \multicolumn{3}{|l|}{ Knowledge } & \multicolumn{3}{|l|}{ Attitude } & \multicolumn{3}{|l|}{ Practice } \\
\hline & Mean (SD) & F/t-test & $P$-value & Mean (SD) & F/t-test & $P$-value & Mean (SD) & F/t-test & $P$-value \\
\hline \multicolumn{10}{|l|}{ Age groups in years } \\
\hline Less than 30 years & $15.17(2.37)$ & 2.587 & 0.010 & $4.12(0.97)$ & 0.969 & 0.001 & $2.33(1.69)$ & 29.537 & $<0.001$ \\
\hline 30 years and more & $15.55(2.04)$ & & & $4.18(0.97)$ & & & $2.93(1.73)$ & & \\
\hline \multicolumn{10}{|l|}{ Gender } \\
\hline Female & 15.35 (2.29) & 0.307 & 0.759 & $4.20(0.91)$ & 1.623 & 0.105 & $2.66(1.69)$ & 1.589 & 0.208 \\
\hline Male & $15.31(2.21)$ & & & $4.10(1.02)$ & & & $2.52(1.76)$ & & \\
\hline \multicolumn{10}{|l|}{ Highest education level } \\
\hline Basic education & $14.60(2.53)$ & 2.301 & 0.022 & $3.87(1.21)$ & 1.983 & 0.048 & $2.19(1.80)$ & 2.457 & 0.117 \\
\hline University and more & $15.37(2.22)$ & & & $4.16(0.96)$ & & & $2.60(1.73)$ & & \\
\hline \multicolumn{10}{|l|}{ Residence } \\
\hline Khartoum State & $15.38(2.26)$ & 0.643 & 0.526 & $4.14(0.94)$ & 1.534 & 0.216 & $2.52(1.68)$ & 50.269 & $<0.001$ \\
\hline Other states & $15.16(2.41)$ & & & $4.07(1.15)$ & & & $1.92(1.68)$ & & \\
\hline Sudanese currently outside & $15.29(1.85)$ & & & $4.28(0.86)$ & & & $3.92(1.42)$ & & \\
\hline
\end{tabular}

direct the health education efforts towards younger and less educated groups.

It's worth noting that 98,95 and $77 \%$ of the population had knowledge about the main preventive measures of the disease spread (handwashing, social distancing, and masks) if this knowledge has been transferred into practice it would make significant difference in the control of the disease.

The attitude of the participants was generally good, with positive significant difference among older and educated groups this was consistent with their knowledge and is consistent with other studies $[6,14]$.

The attitude about wearing face masks was low (49\%) compared to $77 \%$ of the population mentioned it as a mean for controlling the disease. This could be attributed to several factors: inconsistency in the information between different sources such as WHO, CDC, and $\mathrm{MoH}$ which was the same case in Egypt $[16,17]$. There was no law enforcement of the masks use unlike the situation in China and Saudi Arabia [6, 14]. Other possible factors include the high prices of masks and their availability in the Sudanese market, the latter factor has been a global issue [16].

The mean practices score was relatively low compared to high knowledge and good attitude of the participants. This finding brings the importance of improving the accessibility to preventive measures such as availability of handwashing facilities, facemasks, and enforcing social distancing in different facilities.

Table 4 predictors of practices items related to COVID-19

\begin{tabular}{|c|c|c|c|c|c|c|c|c|c|}
\hline \multirow[t]{2}{*}{ Variable } & \multicolumn{3}{|c|}{ I practice hand washing frequently } & \multicolumn{2}{|c|}{ I practice social distancing } & \multicolumn{4}{|c|}{ I avoid hand shaking } \\
\hline & mean & $\mathrm{F} / \mathrm{t}$ test & $P$ value & mean & F/t test & $P$ value & mean & F/t test & $P$ value \\
\hline \multicolumn{10}{|l|}{ Age groups } \\
\hline Less than 30 years & 0.62 & 37.854 & $<0.001$ & 0.60 & 01.047 & 0.307 & 0.23 & 13.644 & $<0.001$ \\
\hline 30 and more & 0.80 & & & 0.63 & & & 0.33 & & \\
\hline \multicolumn{10}{|l|}{ Gender } \\
\hline Female & 0.73 & 04.044 & 0.045 & 0.64 & 02.607 & 0.107 & 0.29 & 01.672 & 0.196 \\
\hline Male & 0.67 & & & 0.59 & & & 0.25 & & \\
\hline \multicolumn{10}{|l|}{ Highest education level } \\
\hline Basic education & 0.57 & 3.264 & 0.071 & 0.57 & 0.245 & 0.620 & 0.23 & 0.315 & 0.575 \\
\hline University and more & 0.70 & & & 0.61 & & & 0.27 & & \\
\hline \multicolumn{10}{|l|}{ Residence } \\
\hline Khartoum State & 0.70 & 23.693 & $<0.001$ & 0.60 & 19.767 & $<0.001$ & 0.23 & 73.734 & $<0.001$ \\
\hline Other states & 0.52 & & & 0.49 & & & 0.15 & & \\
\hline Sudanese currently outside & 0.90 & & & 0.86 & & & 0.71 & & \\
\hline
\end{tabular}


Table 5 Results of binary logistic regression on factors associated with knowledge score

\begin{tabular}{lll}
\hline Variable & OR (95\% Cl) & $P$ value \\
\hline Age groups(less than 30 vs 30 and more) & $0.618(0.470-0.812)$ & 0.001 \\
Gender male (vs female) & $1.224(0.939-1.596)$ & 0.135 \\
Education university and more (vs no university) & $0.519(0.283-0.953)$ & 0.034 \\
Area of residence & & 0.195 \\
Area of residence Khartoum state (vs others) & $1.419(0.927-2.172)$ & 0.107 \\
Area of residence outside Sudan(vs others) & $1.213(0.859-1.712)$ & 0.273 \\
\hline
\end{tabular}

The Sudanese community is a sociable active community which influenced the avoidance handshaking (27\%) and social distancing unlike the situation in other countries like Saudi Arabia where 88\% avoided handshaking [14].

This study demonstrated that the area of residence affects the practices related to the preventive measures especially in those outside Sudan despite the lack of the significant effect on the knowledge and attitude; this might be explained by accessibility to hygiene materials and strict regulations.

It is known that hand hygiene is a major element in the prevention of COVID-19 and other infectious disease. Poor hand washing practice is more linked with male gender, younger age and residence outside Khartoum. This might be due to several factors such as males and young people tend to take more risky behavior as shown in different studies [6]. Beside that in the states, the social networks are more active with less available services.

The good knowledge and attitude has not been translated to satisfactory practices. Which will affect the combating of this virus as the action is mainly based on the community engagement and behavioral changes [14].

Table 6 Results of binary logistic regression on factors associated with practices score

\begin{tabular}{|c|c|c|}
\hline Variable & OR $(95 \% \mathrm{Cl})$ & $P$ value \\
\hline $\begin{array}{l}\text { Age groups(less than } \\
30 \text { vs } 30 \text { and more) }\end{array}$ & $2.022(1.531-2.670)$ & $<0.001$ \\
\hline Gender male (vs female) & $1.537(1.170-2.020)$ & 0.002 \\
\hline $\begin{array}{l}\text { Education university } \\
\text { and more (vs no university) }\end{array}$ & $0.816(0.428-1.554)$ & 0.535 \\
\hline Area of residence & & $<0.001$ \\
\hline $\begin{array}{l}\text { Area of residence } \\
\text { Khartoum state (vs others) }\end{array}$ & $4.460(2.614-7.611)$ & $<0.001$ \\
\hline $\begin{array}{l}\text { Area of residence } \\
\text { outside Sudan(vs others) }\end{array}$ & $0.584(0.408-0.838)$ & 0.003 \\
\hline knowledge score good (vs poor) & $1.152(0.883-1.502)$ & 0.296 \\
\hline Attitude score good (vs poor) & $1.050(0.805-1.370)$ & 0.719 \\
\hline
\end{tabular}

Implication of the findings on the health system

The weak infrastructure, under-resourced health system, widespread of the illiteracy and social practices will negatively influence the spread of the COVID-19 and response towards its prevention.

The study population may not represent the diverse Sudanese communities but it gives an insight to what is happening in Sudan. It is expected that the situation to be worse in more remote and underprivileged areas.

\section{Limitations}

The study was conducted while the country started adopting restrictive measures thus investigators were forced to use online survey methods with its limitations. Access to smartphones and internet is known to be in high and middle socioeconomic classes and among younger age groups and urban areas. The study population may not represent the diverse Sudanese people and the results of this study should not be generalized. Another limitation is the inadequate assessment of the attitudes towards the COVID-19 as the attitude should be measured using Likert scales with more series of questions.

\section{Conclusions}

This study showed that the participants had good knowledge and satisfactory attitude that was not similarly expressed into practice. Efforts are needed in health education and law enforcement to improve the practices among all groups with special emphasis on younger and less educated males.

\section{Supplementary Information}

The online version contains supplementary material available at https://doi. org/10.1186/s12889-021-10319-5.

\section{Additional file 1.}

Acknowledgments

The authors would like to acknowledge the efforts of students from AlNahda College in terms of participation in the dissemination of the questionnaire through social media platforms and assistance in data management. 


\section{Authors' contributions}

Study design AM, EMM. Implementation of the study AM, EM, AAM, HAE, MAM, MES, MIB, RBA, WII, EAM. Statistical analysis AM, AOM, AAM, HAE, MAM, MES, MIB, RBA, WII, EMM. Manuscript drafts AM, EMM, EAM, AOM. All authors read and approved the final manuscript.

\section{Funding}

Al-Nahda College. Al- Nahda College administration did not participate in the design the design of the study and collection, analysis, and interpretation of data and in writing the manuscript.

\section{Availability of data and materials}

All data generated or analyzed during this study are included in this published article and its supplementary information files.

\section{Ethics approval}

The technical approval and ethical clearance were obtained from the Nahda Research Committee (Institution Review Board-IRB). Written informed consent was taken from each participant, participation was voluntary, and the data of the participants was kept confidential with the principal investigator.

\section{Consent for publication}

Not applicable.

\section{Competing interests}

The authors declare that they have no competing interests.

\section{Author details}

${ }^{1}$ Federal Ministry of Health, Khartoum, Sudan. ${ }^{2}$ Faculty of Medicine, University of Khartoum, Khartoum, Sudan. ${ }^{3} \mathrm{Al}$ Nahda College, Khartoum, Sudan.

Received: 27 May 2020 Accepted: 24 January 2021

Published online: 03 February 2021

\section{References}

1. de Wit E, van Doremalen N, Darryl Falzarano VJM. SARS and MERS: recent insights into emerging coronaviruses. Nat Rev Microbiol. 2016;14:523-34 Available from: https://www.nature.com/articles/nrmicro.2016.81.

2. World Health Organization (WHO). WHO Director-General's opening remarks at the media briefing on COVID-19 [Internet]. 2020. Available from: https:/ www.who.int/dg/speeches/detail/who-director-general-s-opening-remarksat-the-media-briefing-on-covid-19-11-march-2020

3. CDC. How to Protect Yourself. 2020. Available from: https://www.cdc.gov/ coronavirus/2019-ncov/prepare/prevention.html

4. Zhao Z, Li X, Liu F, Zhu G, Ma C, Wang L. Prediction of the COVID-19 spread in African countries and implications for prevention and control: A case study in South Africa, Egypt, Algeria, Nigeria, Senegal and Kenya. Sci Total Environ. 2020;729:138959 Available from: https://linkinghub.elsevier.com/ retrieve/pii/S0048969720324761.

5. Adhikari SP, Meng S, Wu Y-J, Mao Y-P, Ye R-X, Wang Q-Z, Sun C, Sylvia S, Rozelle $S$, Hein Raat HZ. Epidemiology, causes, clinical manifestation and diagnosis, prevention and control of coronavirus disease (COVID-19) during the early outbreak period: a scoping review. Infect Dis Poverty. 2020;9 Available from: https://idpjournal.biomedcentral.com/articles/10.1186/s4024 9-020-00646-x

6. Zhong BL, Luo W, Li HM, Zhang QQ, Liu XG, Li WTLY. Knowledge, attitudes, and practices towards COVID-19 among Chinese residents during the rapid rise period of the COVID-19 outbreak: a quick online cross-sectional survey. Int J Biol Sci [Internet]. 2020;16(10):1745-52 Available from: https://www.ijbs. $\mathrm{com} / \mathrm{v} 16 \mathrm{p} 1745 . \mathrm{htm}$.

7. HCT, UNCT. Sudan- Corona virus- COVID-19 Country preparedness and response plan. 2020. Available from: https://reliefweb.int/sites/reliefweb.int/ files/resources/200317_SudanCOVID-19 PreparednessandResponsePlan.pdf.

8. FMOH. epidemic report. Available from: https://fmoh.gov.sd/index.php/files/ download/334. Accessed 12 Apr 2020

9. Geck C. The World Factbook. Charlest Advis. 2017;19(1):58-60 [cited 2020 Aug 10] Available from: https://www.cia.gov/library/publications/the-worldfactbook/geos/su.html\#main-content.

10. Central Bureau of Statistics Sudan. Multiple Indicator Cluster Survey. 2014.
11. Charani E, Cunnington AJ, Yousif AEHA, Seed Ahmed M, Ahmed AEM Babiker $\mathrm{S}$, et al. In transition: current health challenges and priorities in Sudan. BMJ Glob Heal. 2019;4(4):1-8.

12. du Monde M. The KAP survey model (knowledge, Attiudes and practices) content summary; 2012.

13. Violet Alinda, Eyakuze A, Nanyanzi BMM, Melania Akinyi Omengo. Rapid Survey OF Citizens' Knowledge, Attitudes and Practices (KAP) With Respect to COVID-19 in Uganda. [cited 2020 Jul 25]. Available from: https://www. poverty-action.org/recovr-study/rapid-survey-citizens'-knowledge-attitudesand-practices-kap-with-respect-covid-19. Accessed 12 Apr 2020.

14. Al-Hanawi MK, Angawi K, Alshareef N, Qattan AMN, Helmy HZ, Abudawood $Y$, et al. Knowledge, attitude and practice toward COVID-19 among the public in the Kingdom of Saudi Arabia: a cross-sectional study. Front Public Heal. 2020;8(May):1-10.

15. World Health Organisation. RCCE Action Plan Guidance Covid-19 preparedness \& response, vol. 26; 2020. Available from: https://www.who. int/publications-detail/risk-communication-and-community-engagement(rcce)-action-plan-guidance

16. Azlan AA, Hamzah MR, Sern TJ, Ayub SH, Mohamad E. Public knowledge, attitudes and practices towards COVID-19: a cross-sectional study in Malaysia. PLoS One. 2020;15(5):1-15. Available from. https://doi.org/10.1371/ journal.pone.0233668.

17. Samir A, Zeinab A, Maha M, Ibrahim E, Ziady HH, Alorabi M. Knowledge, Perceptions, and Attitude of Egyptians Towards the Novel Coronavirus Disease ( COVID - 19). J Community Health. 2020; Available from. https:// doi.org/10.1007/s10900-020-00827-7.

18. Reuben RC, Danladi MMA, Saleh DA, Ejembi PE. Knowledge, attitudes and practices towards COVID-19: an epidemiological survey in north-Central Nigeria. J Community Health. 2020;(123456789) Available from. https://doi. org/10.1007/s10900-020-00881-1.

19. Nigussie TF, Azmach NN. Knowledge, Attitude and Practice towards COVID19 among Arba Minch Town, Southern Ethiopia. CSJ. 2020;8(6):1283-307.

20. Erfani A, Shahriarirad R, Ranjbar K, Mirahmadizadeh A, Moghadami M. Knowledge, Attitude and Practice toward the Novel Coronavirus (COVID-19) Outbreak: A Population-Based Survey in Iran. [Preprint]. Bull World Health Organ. E-pub: 30 March 2020. https://doi.org/10.2471/BLT.20.256651.

21. Naser AY, Dahmash EZ, Alwafi H, Alsairafi ZK, Al Rajeh AM, Alhartani YJ, HSA FMT. Knowledge and practices towards COVID-19 during its outbreak: a multinational cross-sectional study. medRxiv. 2020; Available from: https:// www.medrxiv.org/content/10.1101/2020.04.13.20063560v1.

\section{Publisher's Note}

Springer Nature remains neutral with regard to jurisdictional claims in published maps and institutional affiliations.

Ready to submit your research? Choose BMC and benefit from:

- fast, convenient online submission

- thorough peer review by experienced researchers in your field

- rapid publication on acceptance

- support for research data, including large and complex data types

- gold Open Access which fosters wider collaboration and increased citations

- maximum visibility for your research: over $100 \mathrm{M}$ website views per year

At BMC, research is always in progress.

Learn more biomedcentral.com/submissions 